\title{
Development and spatial distribution of an algal bloom in the Dead Sea: a remote sensing study
}

\author{
Aharon Oren ${ }^{1, *}$, Nisim Ben-Yosef ${ }^{2}$ \\ ${ }^{1}$ Division of Microbial and Molecular Ecology, The Alexander Silverman Institute of Life Sciences and The Moshe Shilo Minerva \\ Center for Marine Biogeochemistry, The Hebrew University of Jerusalem, Jerusalem 91904, Israel \\ ${ }^{2}$ Applied Physics Division, Graduate School of Applied Science and Technology, The Hebrew University of Jerusalem, \\ Jerusalem 91904, Israel
}

\begin{abstract}
LANDSAT images of the Dead Sea, collected in May 1991 and in April and June 1992, were analyzed to obtain spatial and temporal information on the development of a bloom of unicellular green halophilic algae Dunaliella parva and red halophilic Archaea. While the bacterial carotenoids did not produce a recognizable signal in the images, the presence of chlorophyll-containing algae in high densities in April 1992 was easily detected. The image obtained at the time of the onset of the bloom suggested that the algal bloom originated at the shallow areas near the shore of the lake, and was probably derived from resting cells that survived near the surface of the sediment. Information was also obtained on the mode of mixing of Dead Sea brines with freshwater from the Jordan River and from freshwater springs.
\end{abstract}

KEY WORDS: Remote sensing - Dunaliella $\cdot$ Dead Sea

Fifteen years of quantitative study of the communities of unicellular green algae Dunaliella parva and red halophilic Archaea (family Halobacteriaceae) in the Dead Sea have shown a close correlation between the dynamics of the biota and the physical structure of the water column. Since the overturn of the water column in 1979, periods of stratification have occurred in the Dead Sea: meromixis lasting for several years (1980-1982, 1992-1995) and a period of holomixis lasting almost a decade (1983-1991) (Anati \& Stiller 1991, Beyth et al. 1993). During the holomictic period, the too high salinity of the surface water prevented the development of mass blooms of algae and bacteria in the lake, bacterial densities were low, and algae were altogether absent from the water column (Oren 1988). However, when the upper water layer became sufficiently diluted by winter rain floods, and a stable

•E-mail: orena@shum.cc.huji.ac.il stratification was established, dense populations of Dunaliella developed (8800 cells $\mathrm{ml}^{-1}$ in 1980, more than 15000 cells $\mathrm{ml}^{-1}$ in 1992) (Oren \& Shilo 1982, Oren 1993, Oren et al. 1995). Mass development of Dunaliella was followed by a bloom of halophilic Archaea (up to $2.2 \times 10^{7}$ and $3.5 \times 10^{7}$ cells ml ${ }^{-1}$ in 1980 and 1992, respectively), imparting a red coloration to the water (Oren 1988, Oren \& Gurevich 1995).

Nissenbaum (1975) suggested that some degree of patchiness may occur in the distribution of the biota in the Dead Sea. However, till now little evidence for such patchiness has been documented. One may expect a large degree of spatial variation in algal density at the onset of algal blooms in the Dead Sea. The inoculum from which the Dunaliella develops when conditions become suitable was suggested to be derived either from less saline springs surrounding the lake (Oren \& Shilo 1982, Oren 1989), or from resting stages (cysts), originating from cells that developed during a previous bloom and had sunk to the bottom (Oren et al. 1995).

The meromictic episode that started at the end of 1991 and lasted till the end of 1995 (Oren \& Anati 1996) was caused by a temperature anomaly in the area, caused by the eruption of Mount Pinatubo in the Philippines (Halpert et al. 1993). The cold-air temperature anomaly in the Middle East during the winter of $1991-92\left(3\right.$ to $4^{\circ} \mathrm{C}$ below average) resulted in the addition of about $1.5 \times 10^{9} \mathrm{~m}^{3}$ freshwater to the Dead Sea, causing a level increase of almost $2 \mathrm{~m}$ (Beyth et al. 1993). This new stratification gave rise to a short-lived mass development of algae (April-May 1992) (Oren 1993, Oren et al. 1995) and a prolonged bloom of red bacteria (May 1992 to November 1995) (Oren \& Gurevich 1995, Oren \& Anati 1996). 
In the present study we used remote sensing, involving multispectral analysis of satellite pictures, to observe biological phenomena in the Dead Sea during the spring bloom of microorganisms in 1992. Two multispectral LANDSAT images were obtained from the period of the microbial bloom of 1992: April 15, at the onset of the Dunaliella bloom, and June 22, at a time when the algal bloom had declined and the Dead Sea was colored red by a dense community of halophilic Archaea. For comparison, a LANDSAT image from 5 May 1991 was obtained, collected in a period when Dunaliella cells were altogether absent from the water column, and bacterial numbers were negligible. The images were purchased from the Interdisciplinary Center for Technological Analysis \& Forecasting at Tel Aviv University, Tel Aviv, Israel. All 7 spectral bands were available for analysis: band 1 (0.45-0.515 $\mu \mathrm{m})$, band 2 (0.525-0.605 $\mu \mathrm{m})$, band $3(0.63-0.69 \mu \mathrm{m})$, band $4(0.75-0.9 \mu \mathrm{m})$, band $5(1.55-1.75 \mu \mathrm{m})$, band 6 $(10.4-12.5 \mu \mathrm{m})$, and band $7(2.09-2.35 \mu \mathrm{m})$.
The search for algal and bacterial signatures on the LANDSAT images is based on the effect of the microorganisms on the volume reflectance of the water body. The spectral distribution of the reflected solar radiation is modified by pigments present in the microorganisms. The main interaction commonly measured in such studies is the absorption of sunlight by the red absorption band of chlorophyll contained in the algae, leading to a decrease of the reflection in band 3 (Johnson 1978, Braude et al. 1995, Yacoby et al. 1995). Thus, for analysis we used the ratio of the radiance of band 4 to the radiance of band 3 . This ratio is commonly known as 'algal index' or 'chlorophyll index'. Due to the broad band scattering effect of the algae, the radiance in band 4 will tend to increase with increasing aigai concentration, while due to the specific absorption, the radiance in band 3 will tend to decrease. The use of the ratio neutralizes most of the atmospheric effects. Halophilic Archaea, with their specific absorption by carotenoid pigments ( $\alpha$-bacterioruberin and

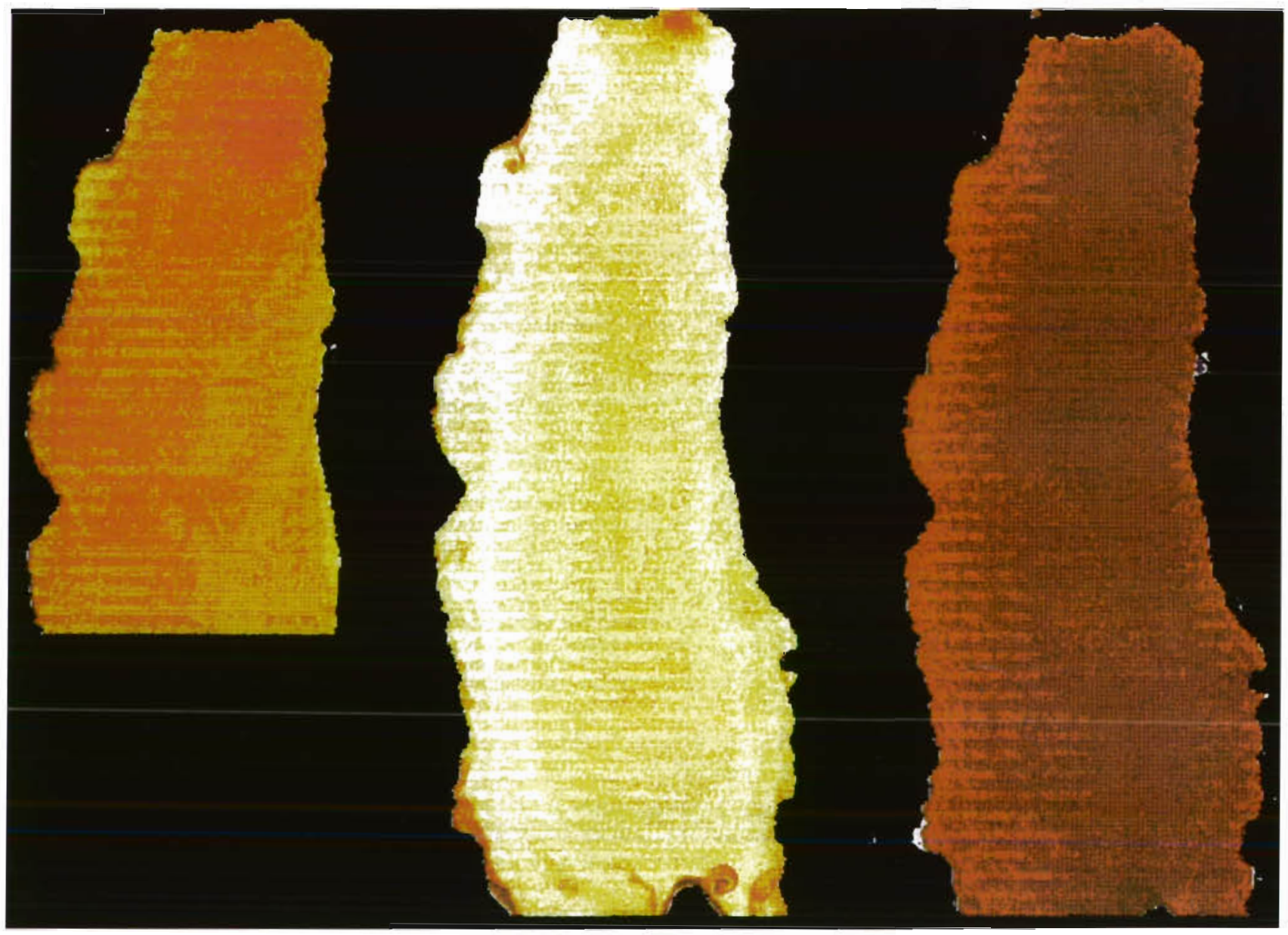

Fig. 1. False color representation of the radiance ratio (band 4/band 3) ('chlorophyll index') in the northern part of the Dead Sea, May 1991 (left panel), April 1992 (middle panel), and June 1992 (right panel). Light (white-yellow) areas represent high radiance ratios, low radiance ratios are shown dark (red) 


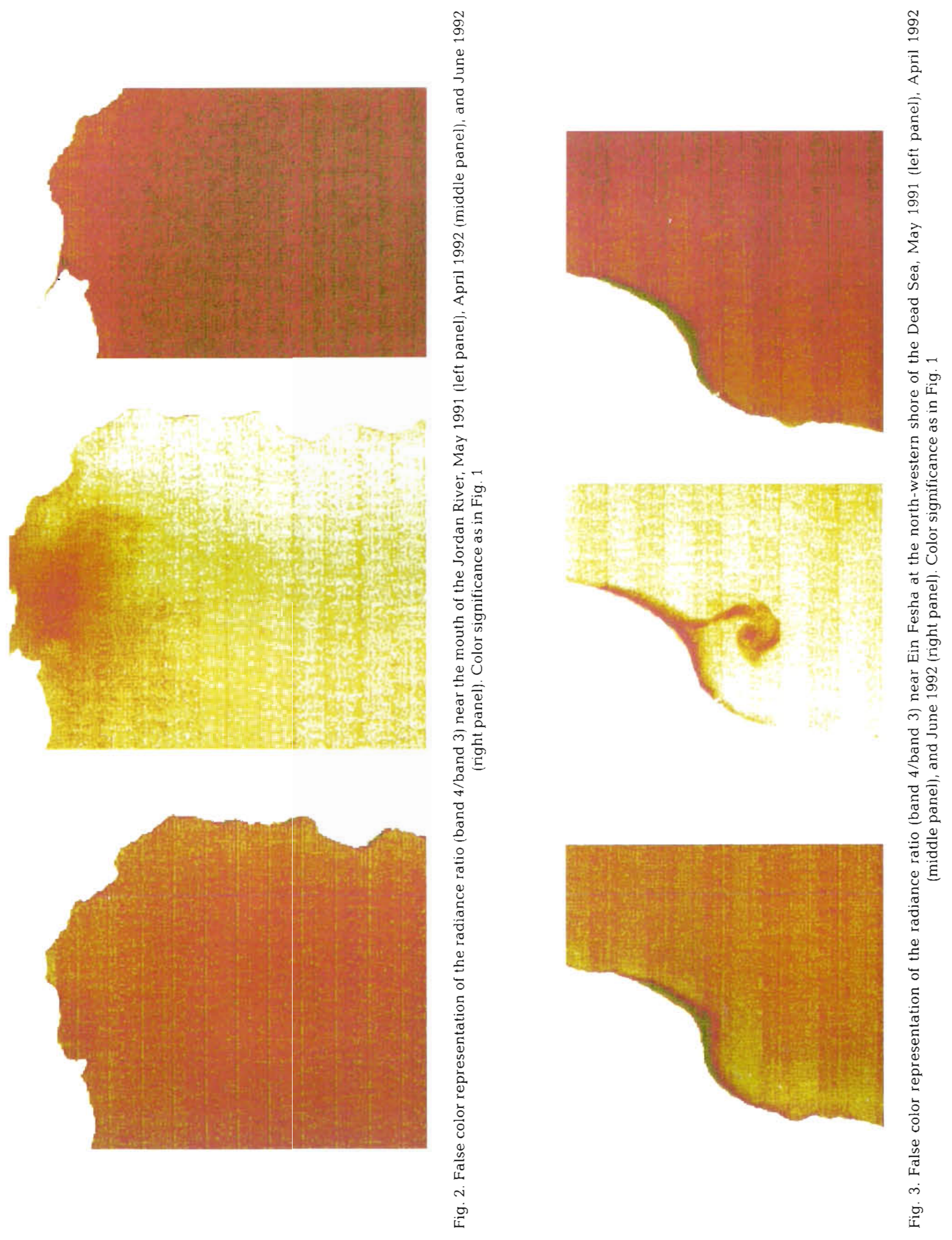


derivatives, showing maximal absorption between 0.45 and $0.55 \mu \mathrm{m}$ ) (Oren \& Gurevich 1995) are expected to cause a decrease of the reflection in band 2 . We attempted to use the attenuation of radiance of LANDSAT band 2 as a measure for the presence of archaeal carotenoids. However, at these short wavelengths spectral data are greatly influenced by atmospheric effects, and comparison of bands 2 and 3 produced results similar to those obtained from bands 3 and 4 . During the 1980-1981 archaeal bloom, bacteriorhodopsin (maximum absorption at $570 \mathrm{~nm}$ ) was present as well (Oren \& Shilo 1981); this pigment was, however, not found in detectable amounts during the 1992 bloom (Oren \& Gurevich 1995).

To supplement remote sensing data, surface water samples were collected in the center of the lake (Table 1). Physical (temperature, salinity) and biological parameters (Dunaliella cell numbers, bacterial density, particulate protein, chlorophyll derived from Dunaliella, and bacterioruberin from halophilic Archaea) were determined as described in previous publications (Oren \& Shilo 1982, Oren 1993, Oren \& Gurevich 1995, Oren et al. 1995, Oren \& Anati 1996).

The average band ratios ('chlorophyll index') in May 1991, April 1992, and June 1992 were 0.59, 0.66, and 0.42 , respectively. As expected, the highest values were observed at the onset of the Dunaliella bloom, with low values in June, when Dunaliella had virtually disappeared from the lake. The intermediate value calculated for May 1991 was unexpected, as at this time the lake was almost devoid of biota. However, radiance values in bands 2 and 3 were higher in June 1992 than in May 1991, possibly indicating high light scattering as a result of the massive presence of bacteria. This hypothesis, however, cannot be proven on the basis of the available data.

All 3 images show a considerable spatial heterogeneity (Figs. 1 to 3). In the 1991 exposure, the band ratio is relatively high near the coast and decreases towards the center, while the opposite is true for the images collected in April and June 1992. This cannot be explained by salinity variations, as the last periods of massive rain in the catchment area of the Dead Sea in the winter of 1991-92 occurred from January 30 to February 13 and from February 23 to 29. However, influx of fresh water from the Jordan River during the period of the investigation should be taken into account $\left(96,96.5,38.3\right.$ and $20 \times 10^{6} \mathrm{~m}^{3}$ in February, March, April, and May 1992, respectively). The general trend in 1992, most pronounced in the April image, is a particularly high chlorophyll index near the shore. The most probable explanation is that here we witnessed the onset of the Dunaliella bloom, and that this bloom originated from resting stages present in the sediment. We observed the formation of such resting cells or cysts during the decline of the 1992 bloom (Oren et al. 1995), and it may be expected that similar resting cells were deposited at the end of the previous bloom in 1980 . The presence of chlorophyll in the bottom sediments of the Dead Sea has been documented earlier (Nissenbaum et al. 1972). The finding of a similarly high 'chlorophyll index' near the southern shores of the lake, where freshwater springs are scarce or absent, supports the hypothesis that cells present in the surface sediment, and not cells derived from less saline springs in the area, formed the inoculum from which the bloom developed. The pattern observed is also in agreement with the bathymetry of the Dead Sea, as the eastern slope is much steeper than the slope near the western shore. Thus, near the western shore, and especially near the southern end of the lake, large areas of surface sediment came into contact with the 5 or $6 \mathrm{~m}$ deep, less saline water layer formed as a result of the massive inflow of freshwater (Oren 1993, Oren et al. 1995). The greatest decrease in salinity occurred in the upper $5 \mathrm{~m}$ only, but in March-April 1992 a decrease in salinity was witnessed down to a depth of 10 or $11 \mathrm{~m}$ (Oren et al. 1995). At greater depths no change in salinity occurred, and thus no signal was present there to trigger the germination of resting Dunaliella cells in

Table 1. Physical and biological parameters of Dead Sea water on sampling days close to the LANDSAT images analyzed ND: not determined

\begin{tabular}{|c|c|c|c|c|c|c|}
\hline Date & 5 Aug 1991 & $18 \operatorname{Mar} 1992$ & 4 May $1992^{a}$ & 20 May 1992 & 15 Jun 1992 & 28 Jun 1992 \\
\hline Salinity $\left(\sigma_{25}\right)^{b}$ & 237 & 167 & 173 & 176 & 181 & 182 \\
\hline Temperature $\left({ }^{\circ} \mathrm{C}\right)$ & 33.5 & 18.8 & 32.9 & 27.7 & 33.5 & $\mathrm{ND}$ \\
\hline Algal cells $\mathrm{ml}^{-1}$ & 0 & 0 & 35000 & 16800 & 2000 & 625 \\
\hline Chlorophyll ( $\mathrm{ug}^{-1} \mathrm{l}^{-1}$ & 0 & 0 & 61 & 24.8 & 2.3 & 1.4 \\
\hline Bacterial cells $\mathrm{ml}^{-1}\left(\times 10^{6}\right)$ & 0.5 & 1.2 & 6.4 & 33 & 29 & 28 \\
\hline Bacterioruberin $\left(\mu \mathrm{g} \mathrm{I}^{-1}\right)$ & ND & ND & ND & 12.6 & 10.2 & 7.0 \\
\hline Particulate protein $\left(\mu \mathrm{g}^{-1}\right)$ & ND & ND & ND & 3.2 & 3.7 & 2.4 \\
\hline
\end{tabular}


the deep sediments. The hypothesis that the Dunaliella bloom started mainly near the shore was also supported by the fact that the highest algal count was recorded in a single sample collected from the western shore (34 000 cells ml-1 $^{-1}$ May 1995) (Oren 1993).

The high chlorophyll index in the Dead Sea in April 1992 made it possible to observe the mode of mixing of water from the Jordan River and additional sources of freshwater, much poorer in algal biomass (Figs. $2 \& 3$, middle panels). The contrast in chlorophyll index between the 2 types of water enables visualization of the mode of mixing freshwater with the Dead Sea brines and the direction of the currents in the lake. A mass of water with a low chlorophyll index was observed, its center located about $1.3 \mathrm{~km}$ southeast of the river's mouth, and flowing in a western direction. In May 1991 and in June 1992, Jordan River water could not be observed because of the small amounts of water discharged and/or because of the insignificant difference in chlorophyll index between the Jordan River water and the Dead Sea brine. A vortex of water with a low chlorophyll index entering the Dead Sea could be observed in April 1992 near the freshwater springs of Ein Fesha (Ein Zuqim) at the northwestern shore (Fig. 3, middle panel). Here the plume of freshwater extended about $2 \mathrm{~km}$ into the lake. A similar vortex can be seen at the southeastern end of the lake (Fig. 1, middle panel). Likewise, the inflow of water from the hypersaline sulfur springs on the shore south of Ein Gedi (Oren 1989) is visible by its low chlorophyll index. No special features were observed in May 1991 or in June 1992 at any of these sites, probably because of the low chlorophyll content of both types of water. In the May 1991 and June 1992 images, no area of high chlorophyll index was evident near the mouth of the Dead Sea. This suggests that no permanent stable area of reduced salinity exists in which dense Dunaliella populations thrive all year round.

It is regrettable that a series of images covering the development of the 1992 bloom (beginning of April to end of May) is no longer available, as such a time series would have shed more light on the origin of the bloom and its spread over the whole lake. However, even now the analysis of LANDSAT images has enabled us to obtain information on the spatial and temporal distribution of the biota in the Dead Sea, information that is difficult to obtain otherwise.

Responsible Subject Editor: Frede Thingstad, Roskilde, Denmark
Acknowledgements. We thank D. A. Anati for supplying data on the physics of the Dead Sea water column, and the Hydrological Service of Israel for data on rainfall and water flow through the Jordan River. This study was supported in part by a grant from the Israel Science Foundation administered by the Israel Academy of Sciences and Humanities (to A.O.).

\section{LITERATURE CITED}

Anati DA, Stiller M (1991) The post-1979 thermohaline structure of the Dead Sea and the role of double-diffusivity. Limnol Oceanogr 36:342-354

Beyth M, Gavrieli I, Anati DA, Katz O (1993) Effects of the December 1991-May 1992 floods on the Dead Sea vertical structure. Israel J Earth Sci 42:45-47

Braude C, Ben-Yosef N, Dor I (1995) Satellite remote sensing of water reservoirs. Int J Rem Sens 16:3087-3114

Halpert MS, Ropelewski CF, Karl TR, Angell JK, Stowe LL, Heim RR Jr, Miller AJ, Rodenhuis DR (1993) 1992 brings return to moderate global temperatures. EOS 74:433-435

Johnson RE (1978) Mapping of chlorophyll-a distribution in coastal zones. Phot Engin Rem Sens 44:617-624

Nissenbaum A (1975) The microbiology and biogeochemistry of the Dead Sea. Microb Ecol 2:139-161

Nissenbaum A, Baedecker MJ, Kaplan IR (1972) Organic geochemistry of Dead Sea sediments. Geochim Cosmochim Acta 36:709-727

Oren A (1988) The microbial ecology of the Dead Sea. In: Marshall KC (ed) Advances in microbial ecology, Vol 10. Plenum, New York, p 193-229

Oren A (1989) Photosynthetic and heterotrophic benthic bacterial communities of a hypersaline sulfur spring on the shore of the Dead Sea (Hamei Mazor). In: Cohen Y, Rosenberg E (eds) Microbial mats. Physiological ecology of benthic microbial communities. American Society for Microbiology, Washington, DC, p 64-76

Oren A (1993) The Dead Sea-alive again. Experientia 49: $518-522$

Oren A, Anati DA (1996) Termination of the Dead Sea 1991-1995 stratification: biological and physical evidence. Israel J Earth Sci 45:81-88

Oren A, Gurevich P (1995) Dynamics of a bloom of halophilic archaea in the Dead Sea. Hydrobiologia 315:149-158

Oren A, Gurevich P, Anati DA, Barkan E, Luz B (1995) A bloom of Dunaliella parva in the Dead Sea in 1992: biological and biogeochemical aspects. Hydrobiologia 297 : $173-185$

Oren A, Shilo M (1981) Bacteriorhodopsin in a bloom of halobacteria in the Dead Sea. Arch Microbiol 130:185-187

Oren A, Shilo M (1982) Population dynamics of Dunaliella parva in the Dead Sea. Limnol Oceanogr 27:201-211

Yacoby YZ, Gitelson A, Mayo M (1995) Remote sensing of chlorophyll in Lake Kinneret using high spectral resolution radiometer and Landsat TM: spectral features of reflectance and algorithm development. J Plankton Res $17: 2155-2173$

Manuscript received: October 14, 1996

Revised version accepted: April 1, 1997 